\title{
BRAzil magnesium (BRAMAG) trial: a double-masked randomized clinical trial of oral magnesium supplementation in pregnancy
}

Carla Adriane Leal de Araújo ${ }^{1,2}$, Joel Geoffrey Ray ${ }^{3 *}$, José Natal Figueiroa ${ }^{4}$ and João Guilherme Alves ${ }^{1}$

\begin{abstract}
Background: There is conflicting evidence about the role of oral magnesium supplementation in the prevention of preterm birth and related adverse outcomes. The objective of this study was to compare magnesium citrate with placebo in the prevention of adverse perinatal and maternal outcomes among women at higher risk.

Methods: This multicenter, double-masked, placebo-controlled randomized superiority clinical trial compared oral magnesium citrate $300 \mathrm{mg}$ to matched placebo, from 12 to 20 weeks' gestation until delivery. This trial was completed in three centers in northeastern Brazil. Eligible women were those with a singleton pregnancy and $\geq 1$ risk factor, such as prior preterm birth or preeclampsia, or current chronic hypertension or pre-pregnancy diabetes mellitus, age $>35$ years or elevated body mass index. The primary perinatal composite outcome comprised preterm birth < 37 weeks' gestation, stillbirth $>20$ weeks, neonatal death or NICU admission < 28 days after birth, or small for gestational age birthweight <3rd percentile. The co-primary maternal composite outcome comprised preeclampsia or eclampsia < 37 weeks, severe gestational hypertension < 37 weeks, placental abruption, or maternal stroke or death during pregnancy or $\leq 7$ days after delivery.
\end{abstract}

Results: Analyses comprised 407 women who received magnesium citrate and 422 who received placebo. The perinatal composite outcome occurred among 75 (18.4\%) in the magnesium arm and 76 (18.0\%) in the placebo group - an adjusted odds ratio (aOR) of 1.10 ( $95 \% \mathrm{Cl} 0.72-1.68)$. The maternal composite outcome occurred among 49 (12.0\%) women in the magnesium arm and 41 women (9.7\%) in the placebo group - an aOR of $1.29(95 \% \mathrm{Cl}$ 0.83-2.00).

Conclusions: Oral magnesium citrate supplementation did not appear to reduce adverse perinatal or maternal outcomes in high-risk singleton pregnancies.

Trial registration: ClinicalTrials.gov NCT02032186, registered January 9, 2014.

Keywords: Pregnancy, Preterm birth, Newborn, Magnesium, Randomized clinical trial, Preeclampsia

\footnotetext{
* Correspondence: Ray」@smh.ca

${ }^{3}$ Departments of Medicine and Obstetrics and Gynaecology, St. Michael's Hospital, University of Toronto, 30 Bond St, Toronto, ON M5B 1W8, Canada

Full list of author information is available at the end of the article
}

(C) The Author(s). 2020 Open Access This article is licensed under a Creative Commons Attribution 4.0 International License, which permits use, sharing, adaptation, distribution and reproduction in any medium or format, as long as you give appropriate credit to the original author(s) and the source, provide a link to the Creative Commons licence, and indicate if changes were made. The images or other third party material in this article are included in the article's Creative Commons. licence, unless indicated otherwise in a credit line to the material. If material is not included in the article's Creative Commons licence and your intended use is not permitted by statutory regulation or exceeds the permitted use, you will need to obtain permission directly from the copyright holder. To view a copy of this licence, visit http://creativecommons.org/licenses/by/4.0/ The Creative Commons Public Domain Dedication waiver (http://creativecommons.org/publicdomain/zero/1.0/) applies to the data made available in this article, unless otherwise stated in a credit line to the data. 


\section{Background}

The World Health Organization (WHO) estimates that each year 15 million children are born preterm before 37 weeks' gestation [1]. Prematurity is a leading cause of death in the neonatal period, and the second most common cause in children under age five years [1-4]. Preterm has immediate and long-term implications for the child, including cerebral palsy, learning difficulties and visual and hearing impairment [5-8]. The ensuing social and economic costs are great [9-11].

Brazil is among the top-10 countries with the highest number of premature births [1]. For example, of the nearly 3 million births registered in the country in 2015, about $10.8 \%$ were preterm [12]. In that same year, prematurity was the main cause of death in children under the age of five years [13]. Furthermore, in 2016, a national study identified that the North and Northeast regions of Brazil had the highest rates of preterm birth, at 13.0 and $12.9 \%$, respectively [14]. Factors associated with prematurity in Brazil are higher social vulnerability -low income, adolescent pregnancy and limited high school education - as well as inadequate prenatal care, a high rate of cesarean delivery and preeclampsia [15].

Magnesium deficiency has been implicated in adverse maternal and perinatal outcomes. Moreover, magnesium deficiency has been associated with an increased risk for gestational and adverse perinatal outcomes, such as gestational hypertensive syndromes, leg cramps and preterm birth [16-21]. Currently, there is no consensus about the daily requirements of magnesium during pregnancy $[21,22]$, with recommendations vary between 220 $\mathrm{mg}$ to $500 \mathrm{mg}$ per day [22]. A recent meta-analysis of 10 randomized clinical trials (RCT), comprising 9090 pregnancies, evaluated oral magnesium supplementation during pregnancy [23]. Therein, oral magnesium did not significantly reduce the risk of preeclampsia, perinatal mortality or small for gestational age birthweight (SGA). Magnesium was associated with higher newborn Apgar scores and less hypoxic-ischemic encephalopathy. However, as only two of the 10 RCTs were considered to be of higher quality, the authors concluded that there is insufficient evidence as to whether oral magnesium supplementation in pregnancy is beneficial to mother or fetus [23]. Additionally, the effect of magnesium supplementation in the prevention of prematurity has had conflicting results, perhaps partly due to different the different forms of magnesium assessed in those trials [24-32].

Magnesium citrate has a high solubility in water, favoring greater intestinal tract absorption and bioavailability compared to other preparations [33]. Accordingly, the current study compared magnesium citrate with placebo in the prevention of adverse perinatal and maternal outcomes among women at higher risk.

\section{Methods}

\section{Study design and setting}

This multicenter, double-masked, placebo-controlled randomized superiority clinical trial was completed between November 2014 and January 2017. The study was conducted in three centers in Northeastern Brazil: Instituto de Medicina Integral Prof. Fernando Figueira (IMIP), Hospital Dom Malan (HDM), and Hospital Petronila Campos. The rate of preterm birth in Northeast of Brazil is about $13.0 \% 11$.

\section{Participant selection}

Eligible women where those with a singleton pregnancy, aged 18 to 45 years, and currently at a gestational age of 12 to 20 weeks, the latter based on the last menstrual period among women with a regular menstrual cycle, or by first-trimester pregnancy dating ultrasound. Additionally, eligibility required that a woman had at least one risk factor for preterm birth or an adverse perinatal outcome, namely, that related to a prior pregnancy (i.e., preterm delivery $<37$ weeks, stillbirth at $>20^{1 / 7}$ weeks, placental abruption, preeclampsia or eclampsia, a liveborn infant with small for gestational age birthweight < 3rd percentile (SGA) or a liveborn infant with birthweight $<2500 \mathrm{~g}$ ), or that in the current pregnancy (i.e., nulliparity, chronic hypertension, type 1 or type 2 diabetes mellitus, maternal age $>35$ years, pre-pregnancy maternal body mass index $>30 \mathrm{~kg} / \mathrm{m}^{2}$, or currently smoking cigarettes). Study exclusion criteria were known uncontrolled hyperthyroidism or active parathyroid disease, a chronic diarrheal disease, a serum creatinine concentration $>1.1 \mathrm{mg} / \mathrm{dL}$, or a serum magnesium concentration $>2.6 \mathrm{mg} / \mathrm{dL}$ at study entry. Before starting magnesium or placebo, serum creatinine and magnesium levels were measured.

Study recruitment was done at the time of a pregnant woman's first consultation at each of the site's outpatient care clinics. Every eligible woman received details about the study's design and goals, and those who provided signed informed consent were included.

\section{Randomization procedure}

Randomization was performed using a table of random numbers, prepared by a researcher who did not participate in the data collection. These numbers were generated in a computer by Random Allocation Software 2.0 program.

\section{Intervention}

Consenting participants allocated to the active arm received a daily magnesium citrate capsule (300 mg elemental magnesium citrate per capsule), and those in the control arm received a daily placebo capsule identical to that in the active arm. While the original protocol plan 
was to administer magnesium citrate $150 \mathrm{mg}$ twice daily [21], it was changed to $300 \mathrm{mg}$ daily, before initiation of the study, to maximize patient compliance. Women were advised to take the capsule after breakfast, daily, until the end of the current pregnancy. Adherence to treatment was defined as the ingestion of at least $80 \%$ of the prescribed dose. The magnesium citrate and placebo capsules were manufactured by IMIP's Department of Pharmacology, and were identical in colour and shape. The $300 \mathrm{mg}$ daily dose of magnesium was chosen to achieve the daily nutritional needs, while minimizing the side effects (e.g., gastrointestinal or sleepiness) or toxicity of excess magnesium. The study medication packages were supplied to each local pharmacy with sequential numbers. Code break envelopes were supplied to the lead pharmacist, but were not available for the investigation team. Each medication pack was individually prescribed for each participant.

Adherence, adverse events, and clinical intercurrences were monitored by the research team at each routine prenatal visit, and every 60 days. Adequate adherence was defined as completion of at least $70 \%$ of the prescribed pill count. Anthropometric data and routine laboratory tests were also performed at these encounters. Pregnant women who did not attend their scheduled clinic visits were contacted by telephone and visited within their residence. Post-randomization losses were duly recorded, with the related reason. Criteria for unplanned study exist were clinical signs or symptoms reported by the patient due to the intake of the capsules, or cancellation of prenatal care at their local hospital.

\section{Outcomes}

The primary perinatal composite outcome comprised preterm birth $<37$ weeks' gestation, stillbirth $>20$ weeks, neonatal death or NICU admission $<28$ days after birth, or small for gestational age birthweight $<3$ rd percentile. The co-primary maternal composite outcome comprised preeclampsia or eclampsia $<37$ weeks, severe gestational hypertension $<37$ weeks, placental abruption, or maternal stroke or death during pregnancy or $\leq 7$ days after delivery. Preeclampsia was defined as an elevated systolic blood pressure $>140 \mathrm{mmHg}$ or diastolic blood pressure > $90 \mathrm{mmHg}$, with $\geq 2+$ proteinuria on urinary dipstick, and/or the HELLP Syndrome, while eclampsia was defined by hypertension and a new-onset seizure. Severe gestational hypertension was identified by nonproteinuric hypertension, with a systolic blood pressure $>160 \mathrm{mmHg}$ or a diastolic blood pressure $>105$ $\mathrm{mmHg}$, and $\leq 1+$ proteinuria. Maternal stroke was defined according to the current WHO definition (a clinical syndrome caused by focal or generalized brain injury that lasts more than $24 \mathrm{~h}$ or leads to death and has no other cause than vascular).

\section{Sample size and data analysis}

At a sample size of 1000 women assigned to placebo and 2000 women assigned to $\mathrm{Mg}^{++}$citrate, with power of $80 \%$ and a 2 -sided $P$-value of 0.05 , the study was equipped to detect at least a $22 \%$ relative risk reduction in the primary perinatal composite outcome, assuming a primary perinatal composite outcome rate of $18 \%$ in the placebo group and $14 \%$ in the $\mathrm{Mg}^{++}$group.

Analyses followed an intention-to-treat principle. Bivariate analysis compared baseline characteristics using a chi-square or unpaired t-test between groups. Study outcomes were presented as rates, and unadjusted relative risks with $95 \%$ confidence intervals (CI). As statistically significant imbalances were seen for two baseline variables - gestational age at trial entry, and cohabitation with a partner - a logistic regression model included these variables, to generate adjusted odds ratios (OR) and $95 \%$ CIs, as planned [20].

Statistical significance was set at a $P$-value $<0.05$. Data analyses were performed using Epi-Info version 7.1.3.10 (CDC, Atlanta) and STATA/SE 12.0.

\section{Patient and public involvement}

No patients were involved in setting the research question or the outcome measures, nor were they involved in developing plans for or implementation of the study. No patients were asked to advise on interpretation or writing up of results.

\section{Results}

Due to a regional Zika virus outbreak, the intended recruitment of 2000 women in the magnesium arm and 1000 women in the placebo arm was not achieved.

Of the 1031 women who were eligible according to study entry criteria, 108 declined to participate and 12 were excluded for other reasons (Fig. 1). In total, 911 women were randomized: 449 to the magnesium citrate arm and 462 to the placebo arm. Of these, 31 (6.9\%) and 25 (5.4\%), respectively, did not complete the trial, because they voluntary abandoned prenatal care at IMIP (19 in the magnesium group and 21 in the placebo group), or moved to other services (12 in magnesium group and 11 in placebo group). Another 11 pregnant women in the intervention group and 15 in the placebo group had symptoms that led them to cease taking the study medication (Fig. 1).

Analyses comprised 407 women who received magnesium citrate and 422 who receivedplacebo. Intention-totreat principle was used. The mean (SD) gestational age at study entry was 15.1 (3.6) and 15.6 (3.8) weeks, respectively. The two groups were similar according to their socio-demographic and clinical characteristics (Table 1). At trial entry, 194 women in the magnesium arm (47.9\%), and 219 women in the placebo arm (52.1\%) 


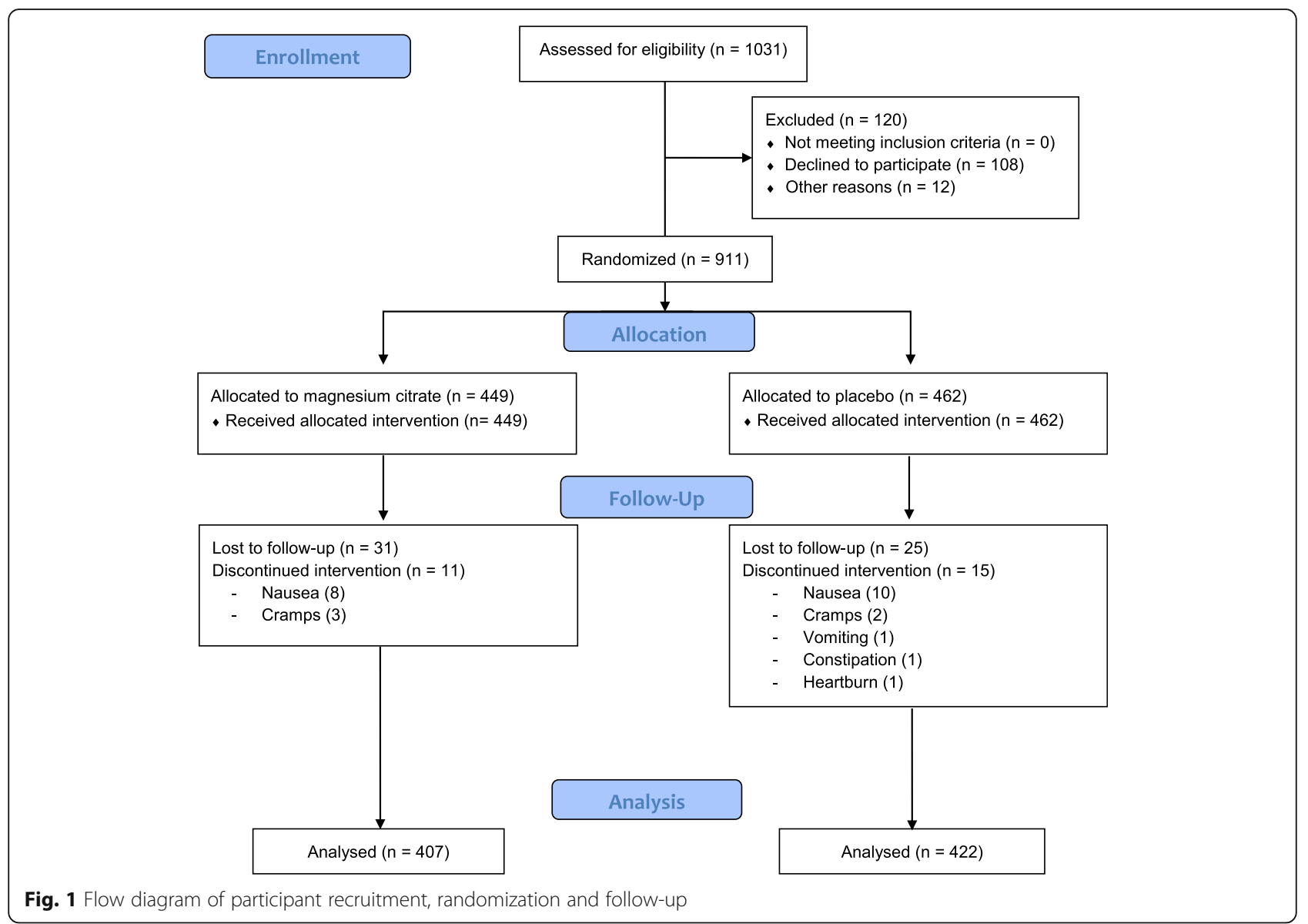

Table 1 Characteristics of study participants at enrollment. All data are shown as a number (\%) unless otherwise indicated

\begin{tabular}{|c|c|c|c|}
\hline Characteristic at enrollment & $\begin{array}{l}\text { Magnesium citrate } \\
(n=407)\end{array}$ & $\begin{array}{l}\text { Placebo } \\
(n=422)\end{array}$ & $P$-value \\
\hline Mean (SD) maternal age, years & $26.9(5.4)$ & $27.2(5.8)$ & 0.53 \\
\hline Mean (SD) gestational age at entry, weeks & $15.1(3.6)$ & $15.6(3.8)$ & 0.05 \\
\hline Lives with partner & $211(51.8)$ & $188(44.5)$ & 0.04 \\
\hline Completed schooling beyond grade 8 & $379(93.3)$ & $388(91.9)$ & 0.44 \\
\hline Currently employed & $221(54.3)$ & $220(52.1)$ & 0.53 \\
\hline Alcohol use disorder & $8(2.0)$ & $12(2.8)$ & 0.41 \\
\hline Current smoker & $5(1.2)$ & $11(2.6)$ & 0.15 \\
\hline Current illicit drug use & $3(0.7)$ & $5(1.2)$ & 0.73 \\
\hline \multicolumn{4}{|l|}{ Pre-pregnancy body mass index, $\mathrm{kg} / \mathrm{m}^{2}$} \\
\hline$<18.5$ & $13(3.2)$ & $11(2.6)$ & \multirow[t]{4}{*}{0.89} \\
\hline 18.5 to 24.9 & $162(39.8)$ & $171(40.7)$ & \\
\hline 25.0 to 29.9 & $136(33.4)$ & $146(34.8)$ & \\
\hline$\geq 30.0$ & $96(23.6)$ & $92(21.9)$ & \\
\hline Pre-pregnancy chronic hypertension & $50(22.1)$ & $60(24.4)$ & 0.59 \\
\hline Gestational diabetes mellitus in a previous pregnancy & $11(4.9)$ & $18(7.3)$ & 0.27 \\
\hline Preterm birth in a previous pregnancy & $38(9.6)$ & $38(9.3)$ & 0.87 \\
\hline Mean (SD) serum magnesium concentration, $\mathrm{mg} / \mathrm{dL}$ & $1.8(0.2)$ & $1.8(0.2)$ & 0.94 \\
\hline Serum magnesium deficiency $<1.8 \mathrm{mg} / \mathrm{dL}$ & $194(47.9)$ & $219(52.1)$ & 0.22 \\
\hline Mean (SD) serum creatinine concentration, mg/dL & $0.5(0.2)$ & $0.5(0.1)$ & 0.80 \\
\hline
\end{tabular}


had a low serum magnesium concentration below 1.8 $\mathrm{mg} / \mathrm{dL}$.

The perinatal composite outcome occurred among 75 $(18.4 \%)$ and $76(18.0 \%)$ pregnancies, respectively (adjusted odds ratio $[\mathrm{aOR}] 1.10,95 \%$ CI $0.72-1.68$ ) (Table 2). The most common event within the perinatal composite outcome was preterm birth $<37$ weeks' gestation (9.3\% vs. $9.0 \%$, respectively) (adjusted OR 1.02, 95\% CI 0.64 to 1.65 ).

The maternal composite outcome occurred among 49 $(12.0 \%)$ and $41(9.7 \%)$ pregnancies, respectively (aOR 1.29, 95\% CI 0.83-2.00) (Table 2). The most common events within the maternal composite outcome were preeclampsia $<37$ weeks' gestation $(5.9 \%$ vs. $4.7 \%)$ and severe gestational hypertension $<37$ weeks' gestation $(4.9 \%$ vs. $4.5 \%)$ (Table 2). Of note, the risk of placental abruption was lower in the magnesium group (9 events [2.2\%]) compared to the placebo arm (21 events [5.0\%]), equivalent to an adjusted OR of 0.43 (95\% CI 0.20 to 0.95 ).

\section{Discussion}

Apparently, in this study, oral magnesium citrate supplementation was not superior to placebo in the prevention of an array of adverse perinatal or maternal outcomes.

The $300 \mathrm{mg}$ daily dose of magnesium citrate used herein approximated that recommended in pregnancy $[22,34]$. A notable proportion of pregnant women (around 50\%) had low serum levels of magnesium. Studies in India, Nigeria and Iran identified hypomagnesemia in pregnancy, at respective rates of 43.6, 16.2 and $13 \%$ $[20,35,36]$. Among 52 healthy pregnant women living in São Paulo, Brazil, despite having serum and red cell magnesium concentrations within normal limits, dietary intake was inadequate, and 39\% had low urinary magnesium excretion [37]. An association between low maternal serum magnesium levels and preterm labour has been described previously [38].

The current findings are in keeping with some previously completed randomized clinical trials of oral magnesium supplementation for the prevention of preterm birth. Martin et al. studied 54 women at high risk of preterm birth, and observed that $1 \mathrm{~g}$ of magnesium gluconate, administered four times daily, was not effective for preventing preterm birth [27]. A double-masked RCT by Sibai et al. evaluated 374 high- risk pregnant women, and also did not show a significant difference in the risk of preterm birth with oral magnesium supplementation [25]. Arikan et al. studied 530 low risk pregnant women, and did not observe any reduction in the risk of preterm labour with oral magnesium citrate, $365 \mathrm{mg}$ daily, started before 18 weeks' gestation [39]. In a quasi-randomized trial of 568 pregnant women receiving magnesium aspartate or placebo, there was a significant reduction in preterm labor in the magnesium arm [24]. Another recent study of 180 pregnant women also found a significant reduction in preterm labor with magnesium in women with hypomagnesemia, using women with a normal serum magnesium concentration as controls [40].

The rate of preterm birth in Northeast Brazil is $12.9 \%$, with a national rate of $11.1 \%$ [41]. Herein, the $9.2 \%$ rate of preterm birth was a little lower than expected, perhaps due to enhanced prenatal care offered within the context of a clinical trial, and the selection of more engaged study participants. There was only one stillbirth observed herein, and 10 neonatal deaths among controls vs. 4 deaths in the magnesium group. While a nonsignificant finding, future studies might consider the potential importance of this outcome related to magnesium supplementation. One study evaluated the risk of newborn hypoxic ischemic encephalopathy among 4082

Table 2 Primary perinatal and maternal outcomes comparing oral magnesium citrate vs. placebo

\begin{tabular}{|c|c|c|c|c|}
\hline Outcome & $\begin{array}{l}\text { Magnesium citrate } \\
(n=407)\end{array}$ & $\begin{array}{l}\text { Placebo } \\
(n=422)\end{array}$ & $\begin{array}{l}\text { Unadjusted relative risk } \\
\text { (95\% confidence interval) }\end{array}$ & $\begin{array}{l}\text { Adjusted odds ratio }{ }^{a} \\
\text { ( } 95 \% \text { confidence interval) }\end{array}$ \\
\hline Primary perinatal composite outcome & $75(18.4)$ & $76(18.0)$ & $1.02(0.76$ to 1.36$)$ & $1.10(0.72$ to 1.68$)$ \\
\hline Preterm birth $<37$ weeks' gestation & $38(9.3)$ & $38(9.0)$ & $1.04(0.68$ to 1.59$)$ & $1.02(0.64$ to 1.65$)$ \\
\hline Stillbirth > 20 weeks' gestation & $0(0.0)$ & $1(0.2)$ & Not calculable & Not calculable \\
\hline Neonatal death $<28$ days after birth & $4(0.9)$ & $10(2.3)$ & $0.41(0.13$ to 1.31$)$ & 0.39 (0.12 to 1.27$)$ \\
\hline NICU admission < 28 days after birth & $12(2.9)$ & $9(2.1)$ & $1.38(0.58$ to 3.24$)$ & $1.38(0.59$ to 3.21$)$ \\
\hline Small for gestational age birthweight $<3$ rd percentile & $21(5.1)$ & $18(4.2)$ & 1.21 (0.65 to 2.24$)$ & 1.37 (0.71 to 2.66$)$ \\
\hline Primary maternal composite outcome & $49(12.0)$ & $41(9.7)$ & 1.24 (0.84 to 1.83$)$ & 1.29 (0.83 to 2.00$)$ \\
\hline Preeclampsia $<37$ weeks' gestation & $24(5.9)$ & $20(4.7)$ & $1.24(0.70$ to 2.22$)$ & 1.25 (0.68 to 2.31$)$ \\
\hline Severe gestational hypertension $<37$ weeks' gestation & $20(4.9)$ & $19(4.5)$ & 1.09 (0.59 to 2.01$)$ & 1.18 (0.62 to 2.26$)$ \\
\hline Placental abruption & $9(2.2)$ & $21(5.0)$ & 0.44 (0.21 to 0.96$)$ & $0.43(0.20$ to 0.95$)$ \\
\hline Maternal stroke during pregnancy or $\leq 7$ days after birth & $0(0.0)$ & $0(0.0)$ & Not calculable & Not calculable \\
\hline Maternal death during pregnancy or $\leq 7$ days after birth & $1(0.2)$ & $0(0.0)$ & Not calculable & Not calculable \\
\hline
\end{tabular}

${ }^{a}$ Odds ratios were adjusted for gestational age at trial entry and cohabitation with a partner, using logistic regression analysis 
pregnant mothers assigned oral magnesium stearate or placebo [30]. Although the rate of medication adherence was about $25 \%$, no reduction in hypoxic ischemic encephalopathy was seen therein. Perinatal mortality was also higher in the treatment group (17 deaths) compared to the placebo arm (7 cases), but most deaths were attributed to congenital anomalies [30]. A recent metaanalysis of magnesium supplementation in pregnant women included 10 trials, with two judged to be of high quality [23]. Analysis restricted to these two trials showed no significant difference between the oral magnesium and control groups for perinatal mortality, SGA or preeclampsia [23].

A major study limitation herein was the lack of achievement of the target sample size. One major reason was an outbreak of microcephaly associated with Zika virus infection [42], which posed a major distraction to participant recruitment and the availability of resources. For example, there was concern among women about the use of medications in pregnancy, given that the etiology of the microcephaly outbreak was unclear at that time. In a post hoc calculation, using the currently achieved study sample size, to detect the expected $22 \%$ relative risk reduction in the primary perinatal composite outcome (i.e., an event rate of $14 \%$ in the magnesium group and $18 \%$ in the placebo group), our study had only $34.9 \%$ statistical power. Even so, the current data do provide important information about the efficacy of magnesium citrate supplementation in pregnancy, and the need to conduct further research in this area.

\section{Conclusions}

Oral magnesium supplementation in pregnancy among higher-risk women does not seen to reduce preterm birth, or adverse perinatal or maternal outcomes.

\section{Abbreviations \\ WHO: World Health Organization; SGA: small for gestational age birthweight; IMIP: Instituto de Medicina Integral Prof. Fernando Figueira; HDM: Hospital Dom Malan; RCT: Randomized clinical trial; Cl: Confidence interval; OR: Odds ratio; SD: Standard deviation; CAM: Centro de Atenção à Mulher}

\section{Acknowledgements \\ The CNPq (Conselho Nacional de Desenvolvimento Científico e Tecnólogico - National Council for Scientific and Technological Development) and the Bill and Melinda Gates Foundation; the Outpatient Care at Centro de Atenção à Mulher (CAM) (Women's Care Center) at the Instituto de Medicina Integral Prof. Fernando Figueira (IMIP).}

\section{Authors' contributions}

This study was originally designed by JGR, JGA and CALA, and implemented by CALA. Data analyses were performed by CALA, JNF, JGR and JGA. CALA wrote the first version of the manuscript, and all the authors contributed to, and approved, the final version.

\section{Funding}

This work was supported by the Conselho Nacional de Desenvolvimento Científico e Tecnológico (CNPq_-process number 401609/2013-8), and Bill \& Melinda Gates Foundation (Investment ID: OPP1107597). The funders had no role in study design, data collection and analysis, decision to publish, or preparation of the manuscript.

\section{Availability of data and materials}

The data are available by establishing contact with the corresponding author at: (email: carla.leal@imip.org.br). The participants gave their consent for data sharing.

\section{Ethics approval and consent to participate}

Potential and consenting participants were informed about the data confidentiality, and were informed about their capacity to withdraw from the study. All the participants provided written informed consent. The study was approved by the Research Ethics Committee at the Instituto de Medicina Integral Prof. Fernando Figueira, document number 4033, and was registered in the ClinicaTrials.gov (NCT 02032186).

\section{Consent for publication}

Not applicable.

\section{Competing interests \\ None.}

\section{Author details}

${ }^{1}$ Department of Pediatrics, Instituto de Medicina Integral Prof. Fernando Figueira (IMIP), Recife, Pernambuco, Brazil. ²Faculdade Pernambucana de Saúde (FPS), Recife, Pernambuco, Brazil. ${ }^{3}$ Departments of Medicine and Obstetrics and Gynaecology, St. Michael's Hospital, University of Toronto, 30 Bond St, Toronto, ON M5B 1W8, Canada. ${ }^{4}$ Department of Biostatistics, Instituto de Medicina Integral Prof. Fernando Figueira (IMIP), Recife, Pernambuco, Brazil.

Received: 27 January 2020 Accepted: 13 April 2020

Published online: 21 April 2020

\section{References}

1. WHO. Preterm birth. Available at: https://www.who.int/en/news-room/factsheets/detail/preterm-birth [accessed December 4, 2019].

2. Newnham JP, Kemp MW, White SW, Arrese CA, Hart RJ, Keelan JA. Applying precision public health to prevent preterm birth. Public Health. 2017:5:66.

3. McCabe ER, Carrino GE, Russel RB, Howse JL. Fighting for the next generation: US prematurity in 2030. Pediatrics. 2014;134(6):1193-9.

4. Blencowe $H$, Cousens S, Chou D, Oestergaard MZ, Say L, Moller AB, et al. Born too soon: the global epidemiology of 15 million preterm births. Reprod Health. 2013;10(Suppl1):S2-14.

5. Araya BM, Díaz M, Paredes D, Ortiz J. Association between preterm birth and its subtypes and maternal sociodemographic characteristics during the post-transitional phase in a developing country with a very high human development index. Public Health. 2017:147:39-46.

6. Strizke A, Thomas, Amin H, Fusch C, Lodha A. Renal consequences of preterm birth. Mol Cell Pediatr. 2017;4(1):2-9.

7. Hovi P, Vohr B, Ment LR, Doyke LW, McGarvey L, Morrison KM, et al. Blood pressure in young adults born at very low birth weight: adults born preterm international collaboration. Hypertension. 2016;68(4):880-7.

8. Bolton CE, Bush A, Hurst JR, Kotecha S, McGarvey L. Lung consequences in adults born prematurely. Thorax. 2015;70:574-80.

9. Raju TNK, Buist AS, Blaisdell CJ, Moxey-Mims M, Saigal S. Adults born preterm: a review of general health and system-specific outcomes. Acta Paediatr. 2017;106(9):1409-37.

10. Soilly AL, Lejeune C, Quantin C, Bejean S, Gouyon JB. Economic analysis of the costs associated with prematurity from a literature review. Public Health. 2014;128(1):43-62.

11. Blac L, Hulsey T, Lee K, Parks DC, Ebeling MD. Incremental hospital costs associated with comorbidities of prematurity. Manag Care. 2015;24(12):54-60.

12. DATASUS Estatísticas vitais. Available at: http://www2.datasus.gov.br/ DATASUS/index.php?area=0205. [accessed May 14, 2019].

13. França EB, Lansky S, MAS R, Malta DC, França JS, Teixeira $R$, et al. Principais causas de mortalidade na infância no Brasil, em 1990 e 2015: estimativas do estudo de Carga Global de Doença. Rev Bras epidemiol. 2017;20(1):46-60.

14. do Carmo Leal M, Esteves-Pereira AP, Nakamura-Pereira M, Torres JA, Theme-Filha M, Domingues RMSM, et al. Prevalence and risk factors related to preterm birth in Brazil. Reprod Health. 2016;13(Suppl 3):164-75. 
15. Leal MC, Esteves-Pereira AO, Nakamura-Pereira N, Torres JA, Theme-Filha M, Domingues RM, et al. Prevalence and risk factors related to preterm birth in Brazil. Reprod Health. 2016;13(Suppl 3):127.

16. Veronese N, Demurtas J, Pesolillo G, Celotto S, Barnini T, Calusi G, et al. Magnesium and health outcomes: an umbrella review of systematic reviews and meta-analyses of observational and intervention studies. Eur J Nutr. 2019 Jan 25. https://doi.org/10.1007/s00394-019-01905-w.

17. Jain S, Sharma P, Kulshreshtha S, Mohan G, Singh S. The role of calcium, magnesium, and zinc in pre-eclampsia. Biol Trace Elem Res. 2010;133:162-70.

18. Idogun ES, Imarengiaye CO, Momoh SM. Extracellular calcium and magnesium in preeclampsia and eclampsia. Afr J Reprod Health. 2007;11: 89-94.

19. Indumati V, Kodliwadmath MV, Sheela MK. The role of serum electrolytes in pregnancy induced hypertension. J Clin Diagnostic Res. 2011;5:65-9.

20. Enaruna NO, Ande A, Okpere EE. Clinical significance of low serum magnesium in pregnant women attending the University of Benin Teaching Hospital. Niger J Clin Pract. 2013;16(4):448-53. https://doi.org/10.4103/11193077.116887.

21. Alves JG, de Araújo CA, Pontes IE, Guimarães AC, Ray JG. The BRAzil MAGnesium (BRAMAG) trial: a randomized clinical trial of oral magnesium supplementation in pregnancy for the prevention of preterm birth and perinatal and maternal morbidity. BMC Pregnancy Childbirth. 2014;14:222. https://doi.org/10.1186/1471-2393-14-222.

22. de Baaij JH, Hoenderop JG, Bindels RJ. Magnesium in man: implications for health and disease. Physiol Rev. 2015 Jan;95(1):1-46.

23. Makrides M, Crosby DD, Bain E, Crowther CA. Magnesium supplementation in pregnancy. Cochrane Database Syst Rev. 2014;4:Cd000937. https://doi. org/10.1002/14651858.CD000937.pub2[PubMed.

24. Spätling L, Spätling G. Magnesium supplementation in pregnancy. A double-blind study. Br J Obstet Gynaecol. 1988 Feb;95(2):120-5.

25. Sibai BM, Villar MA, Brazy E. Magnesium supplementation during pregnancy: a double-blind randomized controlled clinical trial. Am J Obstet Gynecol. 1989;161:115-9.

26. DÀlmeida A, Carter JP, Anatol A, Prost C. Effects of a combination of evening primrose oil (gamma linolenic acid) and fish oil (eicosapentaenoic + docahexaenoic acid) versus magnesium, versus placebo in preventing pre-eclampsia. Women Health. 1992;19(2-3):117-31.

27. Martin RW, Perry KG Jr, Hess LW, Martin JN Jr, Morrison JC. Oral magnesium and the prevention of preterm labor in a high-risk group of patients. Am J Obstet Gynecol. 1992;166:144-7.

28. Dahle LO, Berg G, Hammar M, Hurtig M, Larsson L. The effect of oral magnesium substitution on pregnancy-induced leg cramps. Am J Obstet Gynecol. 1995 Jul;173(1):175-80.

29. Meier B, Huch R, Zimmermann R, von Mandach U. Does continuing oral magnesium supplementation until delivery affect labor and puerperium outcome? Eur J Obstet Gynecol Reprod Biol. 2005;123:157-61.

30. Harrison V, Fawcus S, Jordaan E. Magnesium supplementation and perinatal hypoxia: outcome of a parallel group randomised trial in pregnancy. BJOG. 2007:114:994-1002.

31. Nygaard IH, Valbø A, Pethick SV, Bøhmer T. Does oral magnesium substitution relieve pregnancy-induced leg cramps? Eur J Obstet Gynecol Reprod Biol. 2008;141:23-6.

32. Bullarbo M, Ödman N, Nestler A, et al. Magnesium supplementation to prevent high blood pressure in pregnancy: a randomised placebo control trial. Arch Gynecol Obstet. 2013:288:1269-74.

33. Walker AF, Marakis G, Christie S, Byng M. Mg citrate found more bioavailable than other mg preparations in a randomised, double-blind study. Magnes Res. 2003;16:183-91.

34. Gröber U, Schmidt J, Kisters K. Magnesium in prevention and therapy. Nutrients. 2015;7(9):8199-226.

35. Pathak P, Kapil U, Kapoor SK, Saxena R, Kumar A, Gupta N, Dwivedi SN, Singh $R$, Singh $P$. Prevalence of multiple micronutrient deficiencies amongst pregnant women in a rural area of Haryana. Indian J Pediatr. 2004;71(11): 1007-14.

36. Tabrizi FM, Pakdel FG. Serum Level of Some Minerals during Three Trimesters of Pregnancy in Iranian Women and Their Newborns: A Longitudinal Study. Indian J Clin Biochem. 2014;29(2):174-80. https://doi. org/10.1007/s12291-013-0336-X.

37. Rocha VS, Lavanda I, Nakano EY, Ruano R, Zugaib M, Colli C. Calcium and magnesium status is not impaired in pregnant women. Nutr Res. 2012;32(7): 542-6.
38. Okunade KS, Oluwole AA, Adegbesan-Omilabu MA. A Study on the Association between Low Maternal Serum Magnesium Level and Preterm Labour. Adv Med. 2014;2014:704875. https://doi.org/10.1155/2014/704875.

39. Arikan GM, Panzitt T, Gücer F, et al. Course of maternal serum magnesium levels in low-risk gestations and in preterm labor and delivery. Fetal Diagn Ther. 1999;14:332-6.

40. Zarean E, Tarjan A. Effect of magnesium supplement on pregnancy outcomes: a randomized control trial. Adv Biomed Res. 2017;6:109-14.

41. DATASUS. Estatísticas vitais. Available at: http//tabnet.datasus.gov.br/cgi/ deftohtm.exe?sinasc/cnv/nvuf.def. [Accessed in May 14, 2019]..

42. Souza Al, de Siqueira MT, Ferreira ALCG, de Freitas CU, Bezerra ACV, Ribeiro AG, Nardocci AC. Geography of Microcephaly in the Zika Era: A Study of Newborn Distribution and Socio-environmental Indicators in Recife, Brazil, 2015-2016. Public Health Rep. 2018;133(4):461-71. https://doi.org/10.1177/ 0033354918777256.

\section{Publisher's Note}

Springer Nature remains neutral with regard to jurisdictional claims in published maps and institutional affiliations.
Ready to submit your research? Choose BMC and benefit from:

- fast, convenient online submission

- thorough peer review by experienced researchers in your field

- rapid publication on acceptance

- support for research data, including large and complex data types

- gold Open Access which fosters wider collaboration and increased citations

- maximum visibility for your research: over $100 \mathrm{M}$ website views per year

At BMC, research is always in progress.

Learn more biomedcentral.com/submissions 